\begin{tabular}{|c|c|c|}
\hline 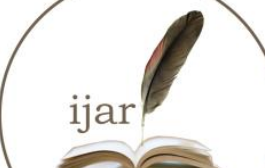 & $\begin{array}{l}\text { Journal Homepage: }-\underline{w w w . j o u r n a l i j a r . c o m} \\
\text { INTERNATIONAL JOURNAL OF } \\
\text { ADVANCED RESEARCH (IJAR) }\end{array}$ & 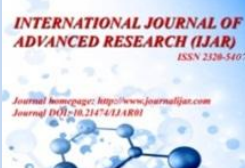 \\
\hline ISSN & $\begin{array}{l}\text { Article DOI:10.21474/IJAR01/8474 } \\
\text { DOI URL: http://dx.doi.org/10.21474/IJAR01/8474 }\end{array}$ & \\
\hline
\end{tabular}

RESEARCH ARTICLE

\title{
PERSONAL IDENTITY IN SPACE PERSONALIZATION OF THE APARTMENT RECEPTION AREA, INENVIRONMENTAL BEHAVIOR CONTEXT.
}

1. Department of Interior Design.

\section{Susy Budi Astuti ${ }^{1}$ and Lea Kristina Anggraeni ${ }^{2}$.}

2. Institut of Technology SepuluhNopember -ITS Surabaya, Indonesia.

\section{Manuscript Info}

Manuscript History

Received: 02 December 2018

Final Accepted: 04 January 2019

Published: February 2019

\section{Abstract}

Personalization is an individual or group behavior of privacy towards the ownership of objects or places, as physical or non-physical objects. The apartment reception area is a shared area that involves privacy and public behavior. Therefore, personalization in this reception area is presented by the character of the residents' behavior. The apartment is managed with a high-security system so that the privacy of residents is maintained. In the reception area which is a shared space, there are some interactions betweenresidents with officersand residents with visitors. Privacy of residents is released/shared with officers or visitors because there is ownership of personal identity.

This research aims to understand the character of the resident's identity in the reception area as a form of sharing in the privacy mechanism in the apartment reception area. This research uses a typical case phenomenology approach. Observation strategies are held by directly observing behavior and physical traces. Structured interviews are also conducted in order to dig deeper into unrecorded objects during direct observation

Personal identity in space personalization of the apartment reception area implies trusts and identity tools, Residents have trust in officers so that theiridentity reliance on the officers becomes a privacy interest. For the public interest, residents represent their identity reliance to the officer in public interest (e.g. to visitors). The resident's personal identity becomes very meaningful when changing intoa shared identity form. Identity sharing desired by residents, so that it becomes the character of interaction in the apartment reception area. Personalization is not only about the ownership of objects or places but also by the character of interactions with other subjects.

Copy Right, IJAR, 2019,. All rights reserved.

\section{Introduction:-}

Vertical apartment is residential alternatives that offer many facilities, including a variety of supporting facilities, a security system that guarantees theresidents privacy, and its location that provides easy access to public facilities. Besides physical function, this occupancy also has a social function. The design setting of vertical apartment aims to be used for individual activities as much as possible, while still providing social interaction. This means that living 
satisfaction of verticalapartment, which is shared ownership, is related to the presence of a togetherness sense (Cho et al, 2011). The quality of occupancy is assessed through the character of the residents' behavior review.

Vertical apartment is different from flats. The difference is the types of facilities availability. The apartment provides more complete supporting facilities, including swimming pool, food courts, convenience store, laundry, fitness facilities, and others. Other than that, the apartment has a shared space that becomes joint ownership. Residents have strata tile rights, that is individual ownership of room units and joint ownership of shared space. Residents have an ID card that is used as an access tool to enter the shared space, especially to the lobby. Residents are concerned in the lobby because there is an elevator as the main instrument of vertical circulation. Only residents can freely access the elevator. This means that besides having a security function, this ID card is also a sign of resident privacy.

Altman and Chemers (1980) explain in their research that humans tend to give a sign to identify their own space. Shared space, or semi-public space, is a meeting place for two aspects of behavior, namely privacy and public behavior.Because it is owned and can be accessed privately and publicly, semi-public space becomes the identity of a particular group/community, while socially becomes a symbol of ownership of its members according to the character of its residents. Ownership of ID cards for residentsis a character of their personal identity. Meanwhile, Lopez, RP (2011) stated that the character of the resident's personal identity can be read from the space character.

This statement is appropriate with Altman and Chemers (1980) opinion, that discussing public and private space is related to aspects of ownership, access, and control. Public space can be accessed by the wider community with a variety of interests, while private space is limited to certain segments/populations. Public space means collective because it can be accessed by everyone at any time. Private space means individuals because it can only be accessed by certain individuals or groups.

\section{Concept of Privacy:-}

The concept of privacy has a comprehensive meaning. Altman (1975) stated that some designers and architects describe privacy as the requirement for visual, physical and psychological boundaries. Reaffirmed by Lang (1987), the focus of privacy is the ability of individuals or groups to control the visual, sound and smell aspects to interacting with others.

Altman (1981) and Newell (1995) pointed out that privacy regulation refers to the process of changing and adapting the behavior of human life. Adaptation is a process of openness and closure. Closed privacy behavior is when humans pull out or limit themselves to deal or interact with other people/environment. Otherwise, open privacy behavior is when humans accept to interact with other people and are easily accessible. Altman and Chemers (1980) stated that privacy regulation is a form of 'boundary control'. In certain conditions and times, humans avoid contact or take distance to not interact with others. Fahey (1995) also emphasized in his research that socially, the definition of privacy is a form of behavior that has limitations on other people, as well as on the environment.

There are 4 regulation aspects that influence privacy review according to Altman and Chemers (1980), that is personal space, verbal/non-verbal, physical environment (environmental behavior) and cultural aspects. Privacy behavior is always related to the social environment. Mortanda (2003) observed this case in the Islamic community. Privacy is defined as the existence of gender separation between men and women so that there is a limit in behavior. Women can interact freely with fellow women. It impacts on spatial layout planning, namely the existence of space that can/can't be freely accessed by women. Astuti SB (2018) in her research stated that the privacy of the apartment resident is a form of identity-sharing behavior.

\section{Personal Identity:-}

Identity can be interpreted physically and non-physically. According to Shrout and Fiske (1981), physical personal identity is observed from gesture and way to behave. Willis and Torodov (2006), and Rule and Ambady (2008) reaffirmed that attractive physical appearance can inform personal identity. Besides, there are several elements that become personal characters, such as clothing, vehicles, food, types of music, and other hobbies or pleasures.

Some studies said that personal identity is always associated with a home. For example, the family room is a space for watching television, receiving guests, or even a hobby room. The hospitality of residents and the function of space is very close to the character of the house residents. Reaffirmed by Lopez (2014), space is a mirror of the 
character of theresident's personal identity. For example, a room that is decorated with fresh flowers and natural theme photos or paintings reflects the resident identity who love nature. The facade design of the building reflects the identity of the institutions and companies that use that building.

Wells and Thelen (2002) explained that personal identity differences causespace personalization differences because space personalization is characterized by meaning, status, and preferences of its residents. Identity basically has several meanings as follows:

"The Three Principles of the Process to Produce Uniqueness and Distinctiveness for a Person, Continuity of a CrossTime and Situation of Personal Worth or Social Value (Breakwell, 1986: 24)"

Something that presents uniquely or different from others, is able to present continuously, has personal value and social involvement, is used as an aspect of presenting personal identity. There are special interactions at special places as well.

\section{Gap of Knowledge:-}

This research fills thegap of knowledge in architecture field about personalizing space in vertical occupancy. The substance of architecture knowledge discussion is the pattern of reciprocal relationship between human behavior and built environment (Lang, 1987), especially space personalization behavior. Personalization of space or environment is a privacy mechanism for access control by presenting personal (Altman and Chemers, 1980). Figure 1 below explains the position of the knowledge gap about space personalization which is reviewed in a shared/semi-public space.

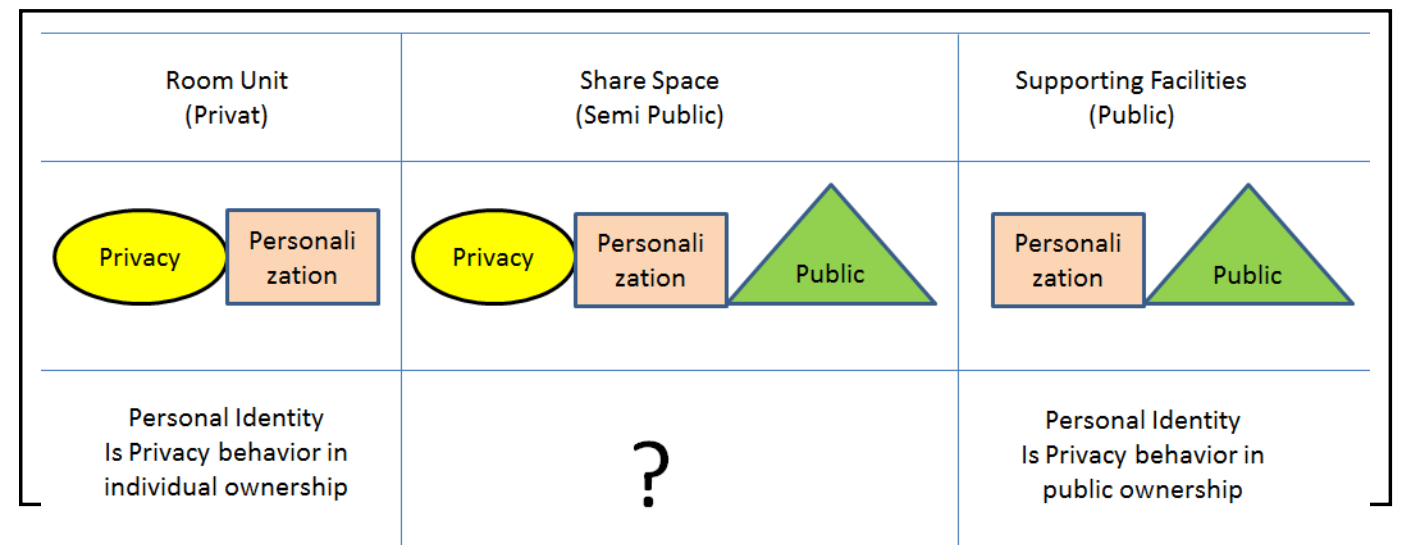

Figure 1:-Gap of Knowledge

Personal identity in individual ownership is a form of privacy behavior. The outcome of privacy is greater than what is needed. This means that personal identity is dominant. Otherwise, personal identity in public ownership is a form of public behavior. The personal identity in a shared space is a form of sharing privacy behaviors in shared ownership. Sharing privacy behavior makes personal identity into a group identity. Based on this, the umbrella theory in this study put the study of personalization behavioron privacy mechanisms according to Altman and Chemers (1980).

\section{Methodology:-}

This study uses qualitative methods with phenomenological approaches. The work method uses Zeisel (1984) analysis through behavioral observation (observing behavior), physical trace observation (observing physical traces), and interviews. These three methods of work are easy to do. Repetition of observations is very possible to do to review and clear the cases that are beyond predictions.

\section{Object Research:-}

This study uses a typical phenomenology case study. Patton (1980) in Muhajir (2000) explained that using typical cases aims to obtain specific information, to avoid rejection. This study does not compare the object of the research case. As qualitative research, Haryadi and Setiawan (1995) explained that research with questionnaires and 
interviews must be continuously observed in order to obtain a high degree of truth. For this reason, the phenomenology research strategy is held by continuous observation (in depth) in the main lobby focusing on the reception area of the apartment.

\section{Case Study Determination:-}

The quality profile of the apartment becomes a choice in behavioral phenomenology approach at a typical case to obtain specific information, not to do a comparison of research objects. The profile of physical environment qualitycanbe a limitation in determining the apartment profile which is chosen as the object of study. Because with the similarity of apartment quality profiles, there are similarities in behavior phenomena and resident characters. Based on this, the selection of apartment quality that is not integrated with public facilities means the apartment building functionminantly is residential. This study was held at Purimas Apartment and Dian Regency Sukolilo in Surabaya, Indonesia.

Purimas Apartment and Dian Regency Sukolilo have the same environmental quality and apartment quality profile. Both are in a residential area. Residents in Purimas and Dian Regency Sukolilo apartments also use residential facilities and are involved in 'behavior' that occurs in residential area. Environmental characteristics impact behavior in apartment supporting facilities, then it impacts behavior in apartment shared space. Based on preliminary observations, the chosen shared-space is the lobby. The lobby is the reception room when entering the building. According to Lee et al. (2010), the lobby is the building entrance area. Besides functioning as the main circulation of residents, it is also a meeting place and interaction between residents, visitors, and officers. The apartment lobby has 3 functions, that is sitting area, reception area, and elevator area. This research is focused on the reception area because this area brings together between residents, managers, and visitors. There is an interaction between residents, residents with managers, residents with visitors, and managers with visitors. So it needs to observe the privacy and public behavior that occurs as a form of privacy mechanisms concept.

\section{Respondents:-}

Questionnaire respondents were residents of selected apartments namely Purimas and Dian Regency Sukolilo in Surabaya, Indonesia. The selection of respondents is based on a direct approach after doing preliminary observations. Besides that, it is also by way of snow-bowling, which is an information chain to their friend/neighbor by contacting their cellphone number. Respondents who were willing to fill questionnaire are 76 people out of 83 people in total from both apartments. The number of 76 respondents dominantly came from Purimas Apartment, which is 51 people. Therefore, this study focuses on uncovering the phenomena that occur in Purimas apartments.

\section{Results:-}

Occupancy in the Reception Area:-

The Relationship of Conformity to Use of Space byPrivacyMechanismsAspects:-

The reception area is not only for information facility, but also as a storage post for residents. Some deposit items include laundry, catering food, or other residents important items, such as keys. Residents feel more comfortable to leave it in the receptionist than bring it out of the apartment. The residentsare permitted to enter the officer area, so that the receptionist area becomes a shared area with the residents, because of familial relationship and trust with the officers. The personal space between the residents and the officers at the receptionist was formed because there were residents' privacy interests and shared interests (Figure 2).

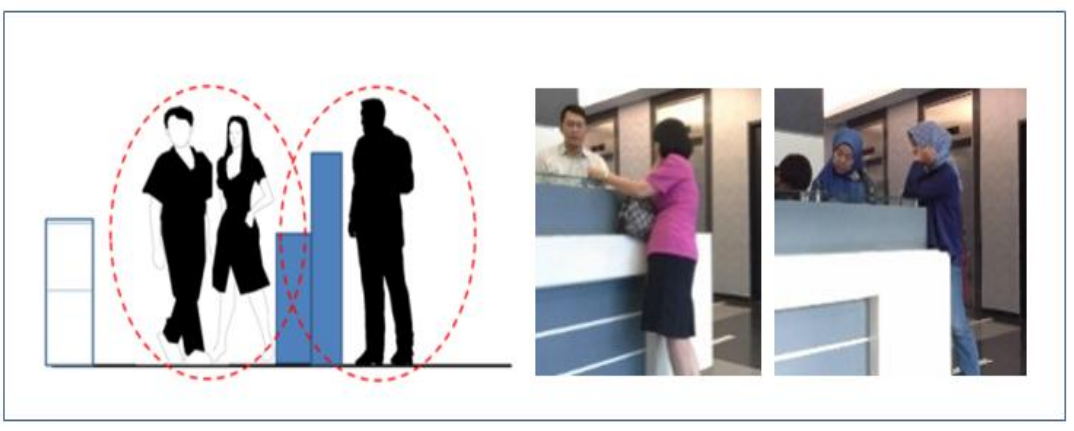

Figure 2:-Formation of Personal Occupancy Room with Officers at the Reception Area Communication is not only greeting in general but up to the personal interest subject because it is related to safekeeping/message. Receptionist acts as an intermediary between residents and other residents/visitors. 
The Relationship between Subjects and Privacy MechanismAspects:-

Interactions that occur between residents in the reception area are the impact of the privacy interests at the reception area. These same and repeated interests finally become the public interest. Residents share with each other for their common/public interests. Figure 3 below is a scheme for the formation of residents personal spaces based on interaction and interestscharacter. The resident's personal space towards officers in privacy interests is smaller than shared/public interests. Residents often appear in the officer area.

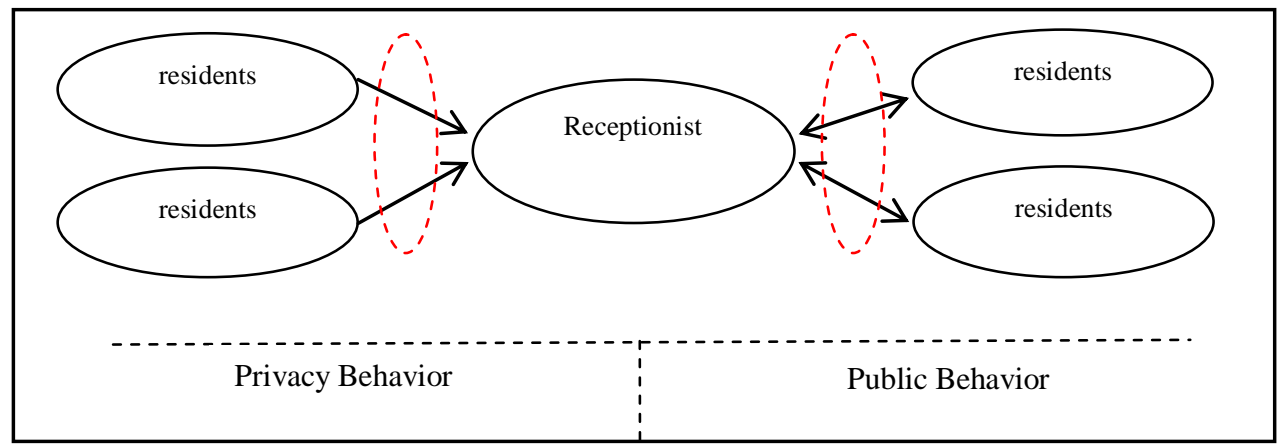

Figure 3:-Personal Room Relationship with Occupancy Interest Character in Reception Area

The interests of visitors to residents or residents to visitors are represented in the reception area. This limitation becomes a simplicity because there is a good relationship with the receptionist. The receptionist is an intermediary between residents and visitors. The 'represented' relationship or interaction is very helpful for residents. Privacy interests 'represented' can be presented at the reception area, because there is trust to the officer.

\section{The Relationship of Sign with Privacy Mechanisms Aspects:-}

Occupancy residentsin the reception area are signed by privacy and public interests. When it comes to privacy, the interactions tend to be familial and close. It is often expressed by the residents moving closer to the officer chair. However, visitors have another behavior. When interacting with officers, they are in the opposite position and 'separated' by the reception desk (Figure 4).

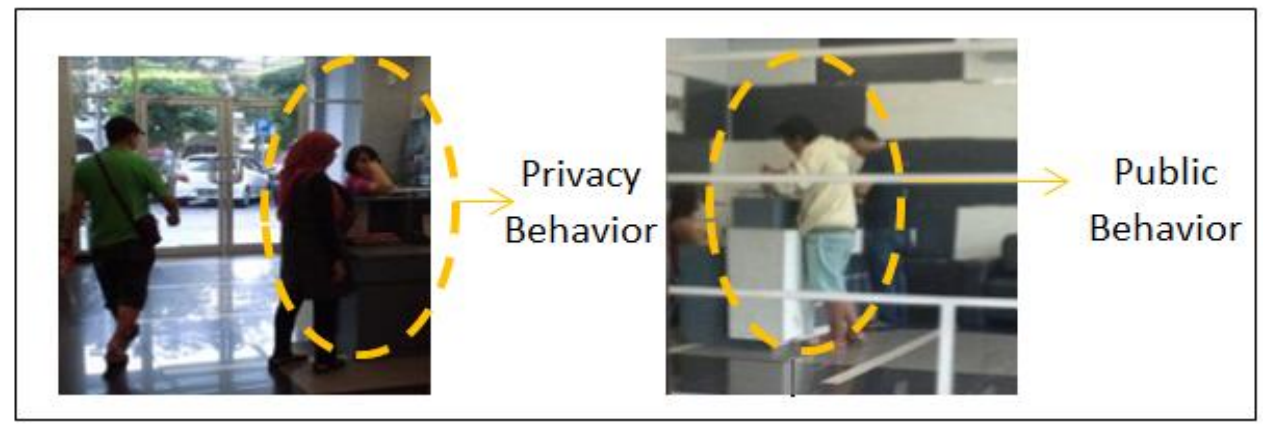

Figure 4:-Position of Residents in the Reception Area When in Privacy / Public Interest

The relationship between residents and officers when interacting is showed by the closeness of personal space that is not physically limited. The resident's privacy interests are inside the officer area. Otherwise, when related to other residents or visitors, they are on the side of residents or visitors. When related to verbal and non-verbal occupancy, when there is verbal interaction inside the receptionist area, it indicates that there is a privacy interest. Otherwise, when residents interact with other residents or visitors verbally/non-verbally in the outside area, then it indicates that there is shared/public interests.

Based on this function, the reception area becomes a 'door' barrier between residents and visitors. Residents do not have to always meet with visitors, because they can be represented by the receptionist. And also visitors do not have to meet with the residents. For example, if the residents order some food with a delivery system, then the food courier can leave the food in receptionist area. The existence of deposit objects/ stuffand indicates the interaction of residents with reception staff or residents with visitors through the receptionist. Figure 5 explains this relationship. 


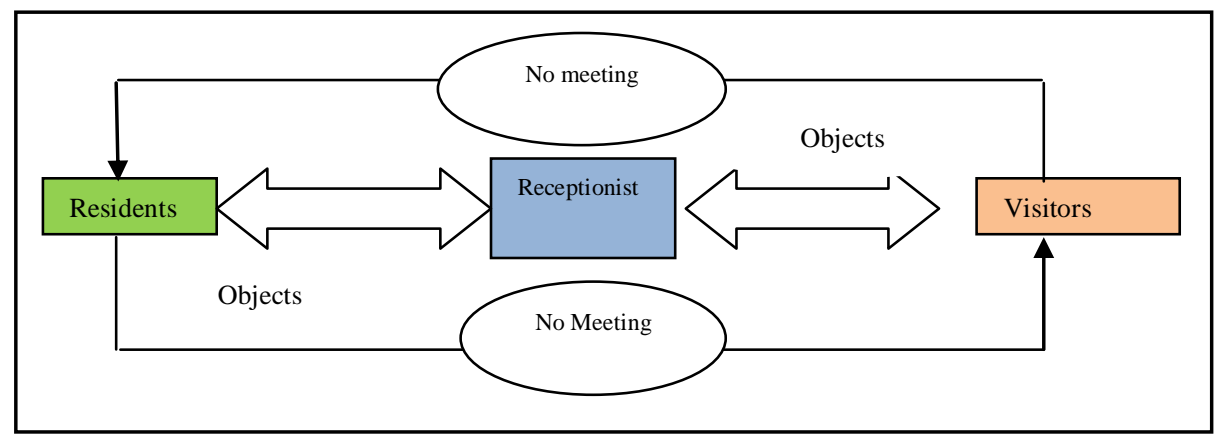

Figure 5:-Delivery Items as a Sign of Occupational Interaction with Officers / Visitors

Space personalization in the reception area is 'represented' personalization by other subjects (officers) because of trust. Trust to the subject becomes a form of trust identity of the residents. The presence of personal and group identities puts the subject as a personalization character.

When behaving privacy, personalization in the reception area is present because of trust to the officer (subject). Whereas when behaving publicly, personalization is formed from group identity due to personal identities sharing to officers, to be delivered to visitors/managers/ other residents.

Ownership of subject 1 (officer) is the most important, then subject 2 (visitor/manager/other residents) are at the next level. It means that subject 1 (officer) existence is the strongest character to form personalization in the apartment reception area. Without the existence of officers, residents will not use the reception area.

Personalization of the reception area occurs directly when the residents interact with subject 1 (officer), so that objects and places become ownership that follows the existence of subject 1. However, space personalization in the reception area can also occur indirectly, because of sharing the resident's personal identity to subject 1 is further shared with subject 2. Further sharing of residents personal identities received by subject 2 is a sign that space personalization in the reception area has a dynamic identity sharing.

Figure 6 below shows personalization based on the level of ownership of the subject, object, and place in the apartment reception area. Circle number 1 is the most important aspect, sequentially to the next number. Based on Figure 6 below, the existence of officers, visitors, and other managers/residents is a determinant of personalization in receptionist area.

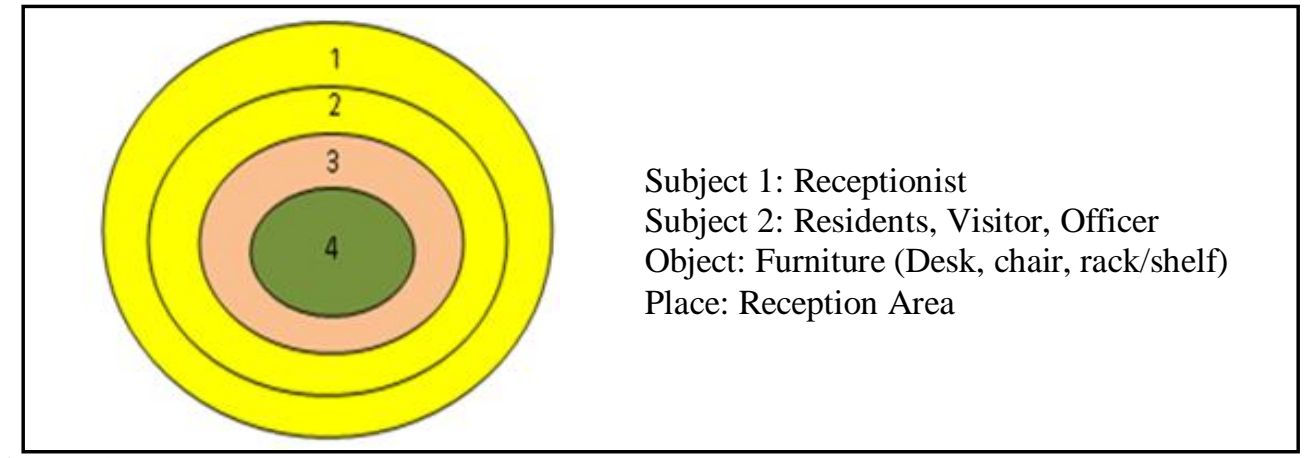

Figure 6 :-Space Personalization Based on the Level of Object Ownership, Subjects and Places in the Reception Area

\section{The Findings of Occupational in The Reception Area:-}

Table 1 below is a discussion summary of the relationship between occupancy aspects and privacy mechanism aspects in receptionist area. The privacy behavior of residents who are present in the reception area is a form of sharing residents with officers, other residents, or with visitors. While Table 2 is the analysis result of each related aspects which are the research findings. 
Table 1:-Occupantional in Reception Area of Purimas's Apartment

\begin{tabular}{|c|c|c|c|c|}
\hline & Personal Space & $\begin{array}{c}\text { Verbal and Non Verbal } \\
\text { Behavior }\end{array}$ & $\begin{array}{c}\text { Environmental } \\
\text { behavior }\end{array}$ & Culture Practice \\
\hline $\begin{array}{c}\text { Suitability } \\
\text { of space } \\
\text { use }\end{array}$ & $\begin{array}{l}\text { The limit personal } \\
\text { space residents and } \\
\text { visitors also by the } \\
\text { existence of the } \\
\text { privacy in order to } \\
\text { give authority to } \\
\text { collect goods or the } \\
\text { interests of other } \\
\text { privacy. The residents } \\
\text { use the area officers to } \\
\text { personal use. }\end{array}$ & $\begin{array}{l}\text { The reception area is } \\
\text { forinformation, control, } \\
\text { and safekeeping. The } \\
\text { relation of interaction } \\
\text { with the officers } \\
\text { dominant in a verbal. } \\
\text { This also happened } \\
\text { between the residents } \\
\text { when meet in the } \\
\text { reception area. The } \\
\text { interaction of non-verbal } \\
\text { occurred because not } \\
\text { interested with officers }\end{array}$ & $\begin{array}{l}\text { A table that high } \\
\text { design and location of } \\
\text { a safe reception area } \\
\text { underscored the } \\
\text { function identity } \\
\text { between privacy and } \\
\text { public behavior.A } \\
\text { standing position in the } \\
\text { area officers and how } \\
\text { to interact with officers } \\
\text { underscored the status } \\
\text { of the resident }\end{array}$ & $\begin{array}{l}\text { The function of the } \\
\text { reception area besides } \\
\text { for share space also } \\
\text { for the residents } \\
\text { privacy. The privacy } \\
\text { behavior present in the } \\
\text { reception area }\end{array}$ \\
\hline User & $\begin{array}{l}\text { Residents and officials } \\
\text { often met so know } \\
\text { each other. Personal } \\
\text { space formed because } \\
\text { of familiarity. The } \\
\text { personal happen } \\
\text { because it had similar } \\
\text { the interests of } \\
\text { privacy. }\end{array}$ & $\begin{array}{l}\text { The distance between the } \\
\text { people to interact with } \\
\text { officials is presented the } \\
\text { level of privacy. The } \\
\text { closer the distance of } \\
\text { inmates to personnel and } \\
\text { verbal interaction } \\
\text { behavior, the more } \\
\text { distant will change to } \\
\text { non-verbal behavior. }\end{array}$ & $\begin{array}{l}\text { The character of the } \\
\text { environment the lobby } \\
\text { determined by a } \\
\text { system of access that is } \\
\text { applied. The lobby is } \\
\text { privacy because } \\
\text { visitors are not free to } \\
\text { enter it. The } \\
\text { atmosphere of the } \\
\text { lobby dominated the } \\
\text { residents.Interaction } \\
\text { with the officers more } \\
\text { often in the area } \\
\text { officers (behind office } \\
\text { desk). }\end{array}$ & $\begin{array}{l}\text { The interests of the } \\
\text { residents of the privacy } \\
\text { to visitors or } \\
\text { otherwise, represented } \\
\text { in the receptionist area } \\
\text { because there is a trust } \\
\text { to officers. }\end{array}$ \\
\hline Sign & $\begin{array}{l}\text { Space and the personal } \\
\text { residentsoccurs } \\
\text { because know each } \\
\text { other, characterized by } \\
\text { physical and non- } \\
\text { physical. }\end{array}$ & $\begin{array}{l}\text { The identity of the } \\
\text { residentssigned from its } \\
\text { material of the verbal } \\
\text { communication with } \\
\text { officers. The table of the } \\
\text { front desk as the } \\
\text { barrierarea in and out, } \\
\text { that has meaning when } \\
\text { therr is an officers. }\end{array}$ & $\begin{array}{l}\text { The reception area } \\
\text { became as a door } \\
\text { between residents and } \\
\text { supporting. } \\
\text { Characterized by } \\
\text { workstations distinct, } \\
\text { separate and protected } \\
\text { from a common } \\
\text { activity. The table } \\
\text { counter and the } \\
\text { receptionist be a sign } \\
\text { to represent its } \\
\text { function }\end{array}$ & $\begin{array}{l}\text { Residents do not have } \\
\text { to always meet the } \\
\text { visitors and the visitors } \\
\text { do not have to meet the } \\
\text { residents. There is a } \\
\text { sign of verbal (non- } \\
\text { physical) and } \\
\text { physically (objects) to } \\
\text { the officer. }\end{array}$ \\
\hline
\end{tabular}

Table 2:-The Findings of Occupational in the Reception Area of Apartment

\begin{tabular}{|l|l|l|l|l|l|l|}
\hline & \multicolumn{2}{|l|}{ Personal Space } & \multicolumn{2}{l|}{ Verbal \&Non Verbal } & $\begin{array}{l}\text { Environment } \\
\text { Behavior }\end{array}$ & $\begin{array}{l}\text { Cultural } \\
\text { Practices }\end{array}$ \\
\hline $\begin{array}{l}\text { Suitability } \\
\text { of space use }\end{array}$ & $\begin{array}{l}\text { Non- } \\
\text { spatial }\end{array}$ & Verbal & Verbal & $\begin{array}{l}\text { know and } \\
\text { trust each } \\
\text { other }\end{array}$ & $\begin{array}{l}\text { High tables make the } \\
\text { reception area } \\
\text { protected }\end{array}$ & $\begin{array}{l}\text { Receptionist Area } \\
\text { use as privacy and } \\
\text { public behavior }\end{array}$ \\
\cline { 2 - 5 } & Spatial & $\begin{array}{l}\text { Zona } \\
\text { personal }\end{array}$ & $\begin{array}{l}\text { Non- } \\
\text { Verbal }\end{array}$ & $\begin{array}{l}\text { No interest } \\
\text { with the }\end{array}$ & $\begin{array}{l}\text { Residents have } \\
\text { interest with the }\end{array}$ & \\
\hline
\end{tabular}




\begin{tabular}{|c|c|c|c|c|c|c|}
\hline \multirow{2}{*}{ 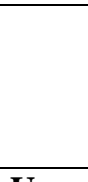 } & & & \multicolumn{2}{|c|}{\begin{tabular}{|l|l|} 
& receptionist \\
\end{tabular}} & \multirow{2}{*}{$\begin{array}{l}\text { receptionist } \\
\text { The Receptionist } \\
\text { desk as identity, not } \\
\text { limiting }\end{array}$} & \\
\hline & \multicolumn{2}{|c|}{$\begin{array}{l}\text { Residents have Privacy } \\
\text { behavior with } \\
\text { Receptionist }\end{array}$} & \multicolumn{2}{|c|}{$\begin{array}{l}\text { Verbal as dominant } \\
\text { interaction }\end{array}$} & & \\
\hline User & $\begin{array}{l}\text { Non- } \\
\text { spatial }\end{array}$ & $\begin{array}{l}\text { Know each } \\
\text { other }\end{array}$ & \multicolumn{2}{|c|}{$\begin{array}{l}\text { Verbal interaction when } \\
\text { close to the receptionist }\end{array}$} & $\begin{array}{l}\text { Resident takes } \\
\text { interaction to }\end{array}$ & \multirow{3}{*}{$\begin{array}{l}\text { The Receptionist as } \\
\text { representatives of } \\
\text { residents to visitors, } \\
\text { or vice versa. There } \\
\text { is sharing trust } \\
\text { identity between } \\
\text { them. }\end{array}$} \\
\hline & spatial & $\begin{array}{l}\text { Residents- } \\
\text { Receptionist }\end{array}$ & \multicolumn{2}{|c|}{$\begin{array}{l}\text { Non Verbal interaction } \\
\text { when far from the } \\
\text { receptionist }\end{array}$} & $\begin{array}{l}\text { Receptionist in } \\
\text { 'internal side' of } \\
\text { receptionist area. }\end{array}$ & \\
\hline & \multicolumn{2}{|c|}{$\begin{array}{l}\text { Resident\& } \\
\text { Receptionist: Personal } \\
\text { space occurs because } \\
\text { recognize and trust } \\
\text { each other. } \\
\text { Between residents: } \\
\text { Personal Space occurs } \\
\text { the similarity needs }\end{array}$} & \multicolumn{2}{|c|}{$\begin{array}{l}\text { The presence of officers } \\
\text { forms privacy for } \\
\text { Residents }\end{array}$} & $\begin{array}{l}\text { residents occupy the } \\
\text { area of the } \\
\text { Receptionist }\end{array}$ & \\
\hline \multirow[t]{3}{*}{ Sign } & $\begin{array}{l}\text { Non- } \\
\text { spatial }\end{array}$ & $\begin{array}{l}\text { The } \\
\text { presence of } \\
\text { Receptionist }\end{array}$ & Verbal & Serious talk & \multirow[t]{2}{*}{$\begin{array}{l}\text { Resident occupy the } \\
\text { receptionist area }\end{array}$} & \multirow{2}{*}{$\begin{array}{l}\text { Residents always } \\
\text { interact with the } \\
\text { receptionist even if } \\
\text { only non-verbally } \\
\text { (smile, nod etc.) }\end{array}$} \\
\hline & Spatial & $\begin{array}{l}\text { High desk } \\
\text { as identity }\end{array}$ & $\begin{array}{l}\text { Non- } \\
\text { verbal }\end{array}$ & $\begin{array}{l}\text { Look, Smile, } \\
\text { nod }\end{array}$ & & \\
\hline & \multicolumn{2}{|c|}{$\begin{array}{l}\text { Sharing spatial dan } \\
\text { non-spatial }\end{array}$} & \multicolumn{2}{|c|}{$\begin{array}{l}\text { Serious verbal sharing } \\
\rightarrow \text { The sign of the } \\
\text { residents }\end{array}$} & $\begin{array}{l}\text { The identity of } \\
\text { residents' personal } \\
\text { interests }\end{array}$ & $\begin{array}{l}\text { privacy needs are } \\
\text { present in the public, } \\
\text { sharing signs of } \\
\text { identity of residents }\end{array}$ \\
\hline
\end{tabular}

\section{The Findings of Space Attachment in The Reception Area:-}

\section{Place Aspect:-}

The dominant attachment in the reception area is where to get information and entrust or collect stuff. Socially, there is an interaction between residents and officers or fellow residents in the reception area. In addition, there are special interactions, that is residents with visitors do not have to meet each other physically or visually because the interaction is represented by the receptionist. These special interactions are beneficial and simplify. Residents feel safe and comfortable when leaving some stuff to the officer in the reception area because there is trust to them.

\section{Person Aspects:-}

The apartment residents have a close attachment to the presence of the receptionist. The officer is able to serve as a management representative who can be visited easily every day. The facility is used by residents to always interact when meeting in the lobby. Process Aspect. The presence of officers all time is ready to serve information and able to connect with the manager, is a very profitable facility for residents. In the lobby room, especially in the reception area, there is always a guard for 24 hours. These conditions provide a sense of security and comfort for apartment residents.

Based on the discussion of place aspects, people aspects, and process aspect, the attachment to the reception area is determined by the following factors: the presence of officers, service systems, the character of the lobby, and the character of apartment environment. Figure 7 below is the space personalization characters in the reception area.

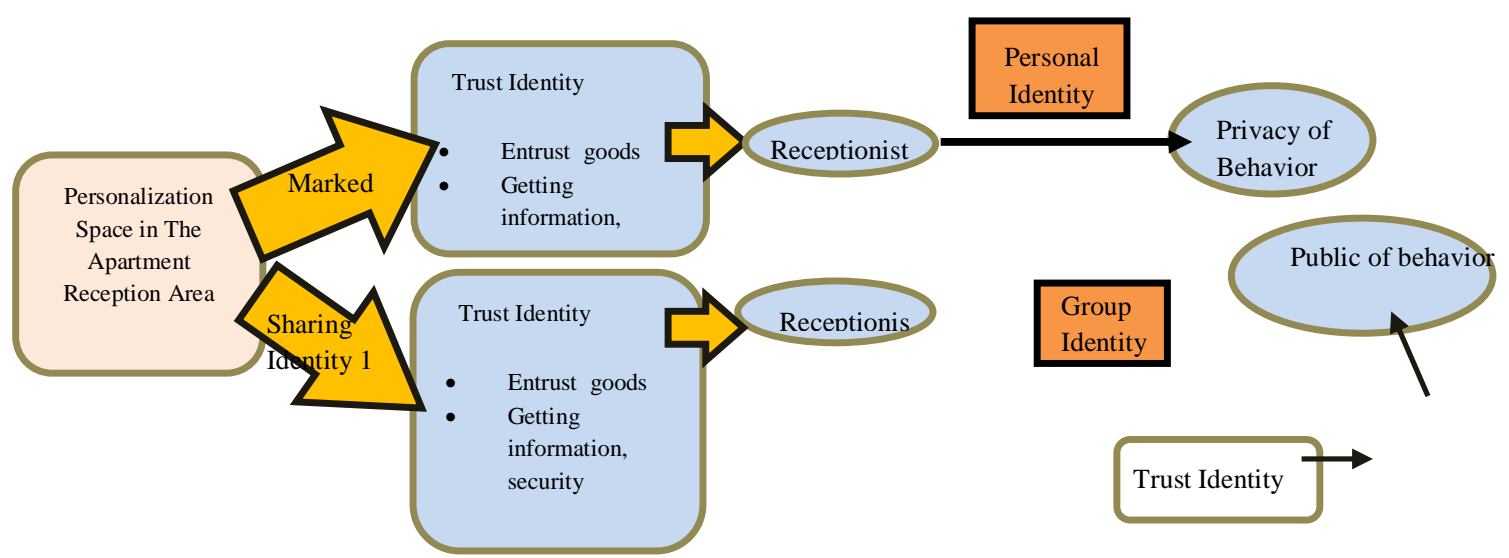



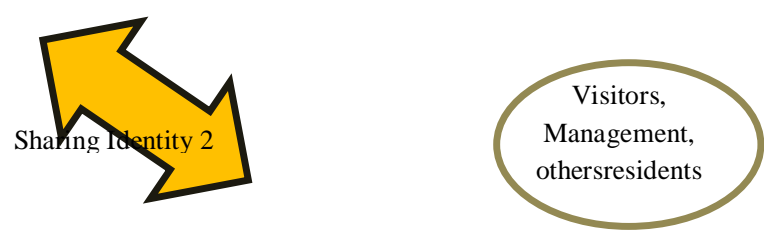

Figure 7:-Character of Personalization Space in The Apartment Reception Area

\section{Conclusion:-}

Personalization in receptionist area is signed with trust identity. Interaction of resident and reception staff is for privacy and public need. For privacy purpose, the resident's trust identity to officers becomesresidents personal identity. Meanwhile, for public interest, identity trust becomes a group identity.

The findingss of this study give the knowledge that occupancy in semi-public areas is a form of privacy behavior in shared identity existence. Identity sharing is desired and needed by apartment residents. Identity sharing that is based on trust is the character of interaction. Identity trust is a form of residents privacy behaviors to sustain life.

\section{Reference:-}

1. Altman,IdanChemers, M. (1980), Culture and Environment, Monterey, California

2. Cho (2011), "A Study on Building Sustainable Communities in High Rise and High Density ApartmentsFocused on Living Program", Building and Environment, Vol.46, pg.1428-1435

3. Fisher, A. Bell, P.A danBaum, A. (2001), Environmental Psychology, Harcourt College Publisher, USA

4. Haryadi and Setiawan, B. (1995), ArsitekturLingkungandanPerilaku, ProyekPengembanganPusatStudiDirjenDikbud, Yogyakarta

5. Lang, J (1987), Creating Architectural Theory, The Role of The Behavioral Sciences in Environmental Design, Van Nostrand Reinhold Company, New York

6. Lee, Yeunsook, Kim K, dan Lee Soojin (2011), "Study on Building Plan for Enhancing the Social Health of Public Apartments", Building and Environments, Vol. 45, pg.1551-1564

7. Lopez, R.P (2011), "Thin Slices of Competence and Warmth via Personalized Primary Spaces", article in Psychology, DOI: 10.1174/217119713807749878

8. Mortada, H. (2003), Traditional Islamic Principles of Built Environment,RoutledgeCurzon, New York.

9. Muhajir, N (2000), MetodologiPenelitianKualitatif, Rake Sarasin, Edisi IV, Yogyakarta

10. Rule, N. O., \&Ambady, N. (2008), “The Face of Success: Inferences from Chief Executive OfficersAppearance Predict Company Profits", Psychological Science, Vol. 19, pg.109-111.

11. Wells, M., \&Thelen, L. (2002), "What does Your Space About You? The Influence of Personality, Status, and Workspace of Personalization", Environment and Behavior, Vol. 34, pg. $300-321$

12. Wills, J., \&Torodov, A. (2006), "First Impressions: Making up Your Mind After a 100-ms Exposure to a Face", Psychological Science, Vol. 17, pg. 592-598. 